\title{
THE STYLE AS A FACTOR OF OFFICE BUILDING CONCENTRATION LOCATIONS IN EUROPEAN CITIES
}

\author{
Anna BOCIAN ${ }^{1}$ \\ Wroclaw University of Technology, Wrocław, Poland
}

\begin{abstract}
Where should office building concentrations be located in cities? What kind of factors has an influence on its locations? The aim of the research is to examine factors of office locations in cities. Selected office building concentrations in European cities were investigated as case studies. The research method was the spatial decision paradigm. The style, one of the main elements of the paradigm, was selected to answer the research question. The style was defined a composition of existing urban structures. Basic elements of urban composition in selected European cities were examined closely. Research results are conditions of office building concentration locations in European cities in term of urban composition. Such knowledge should be a base of decisionmaking processe during preparing master plans and city development plans.
\end{abstract}

Keywords: office building, business district, urban composition

\section{INTRODUCTION}

Many researchers claim that new urban forms can be delaminated in our cities. Urban tissues, like alive organism, adapt to our new requirements and activities. Such relatively new urban forms are office building concentrations. They are usually called business districts. The shift from Fordism to Post-Fordism economy is indicated as a one of main reasons why such new urban forms appeared. A change from industry based to finance and service based economy and new work millennium are main consequences of that changes. Office buildings are now one of the most needed workspaces. It causes a need for new

\footnotetext{
${ }^{1}$ Corresponding author: Wroclaw University of Technology, Faculty of Architecture, Bolesława Prusa st 53/55, 50-317 Wrocław, Poland
} 
office buildings. Clusters of many office buildings have started appearing in cities, which are strong enough on international market. Such huge concentrations of many workplaces have special requirements and cause many issues. Office building concentrations are desirable urban forms by city authorities. But at the same time, they are no sustainable urban structures in spatial and social aspects. Therefore, better knowledge about these urban forms is necessary to understand process of business district locations. New knowledge lets to better plan and manage these districts.

Various aspects of office building concentrations can be researched. Different scales also can be taken under consideration. However, a city scale was selected for this research. Office building concentration locations in city areas were evaluated. The aim of the research was to examine factors, which could have an influence on office locations in European cities. The research question was what kind of factors has an impact on office building locations. The importance of each factor was also analyzed.

\section{RESERCH OVERVIEW}

1. Office building concentrations are a research area for many scientists. However, various aspects can be taken under consideration: economic, spatial or social. Significant research about office buildings was done by Peter Marcuse. He indicated that the globalization process has an impact on office district appearing as new patters in our cities [6]. His research proved also that office building concentrations are unsustainable urban forms. They are more like closed citadels [6,7], unseparated from surrounded districts. Stan Majoor had also similar observation. He indicated that offices create monofunctional districts [5]. These urban tissues require contacts with other metropolitan forms and efficient transport to them, rather than good access to other city districts [5]. Also many researchers, such as Saskia Sassen [8], tried to prove that office building concentrations are new urban forms in our cities. Those new structures appeared in European cities at the end of the XX century. All scientists indicate influences of the global market and international economic processes. Local connections for offices seem to be not so strong and significant.

2. However, it is emphasized that cities should be more attractive for people than for investors. People are the power of companies. Richard Florida indicated that especially those creative people are looking for by companies. His research showed that creative class is a group of people, who are the power of many companies [1]. But those people require more from cities they live at the same time. Such cities have to be fashionable and attractive enough for creative people [1]. A similar point of view is represented by Edward Glaeser. His 
research proves strong connections between people working in office building concentration and local city aspect [2].

3. Therefore, the research overview shows that access to two types of activities should be provided from office building concentrations. On one hand, a strong need for contacts with international and metropolitan activities is required. That type of connections should satisfy economic needs of investors. On the other hand, social requirements have to be also done. Cities should be attractive enough for employees.

\section{RESERCH METHOD}

The case study method was chosen as a research method. Representative and characteristic examples of office building concentrations from European cities were selected and examined. To answer the research question - define indicators of office building concentration locations, the decision-making paradigm was chosen [11]. The paradigm contains eight elements. All of them support spatial decision-making processes. However, only one element of the paradigm the style was chosen to examine the impact of the urban composition on office location. The style is defined as an urban composition in this research. Various elements of the urban composition were deeply analyzed. Those elements based on Kevin Lynch theory [4]. All elements of a mental map were taken under consideration: paths, edges, districts, nodes, landmarks. Because of research question concerns office building locations in cities, all elements were examined in a city scale. Relations between these elements and office locations were examined for each city.

Each element of a mental map was defined for this research. As paths were considered all the most important roads in cities: highways and main roads. Those roads are main transportation corridors in the city scale, therefore, were analyzed as paths. The next element, edges were understood as important borders in a city scale. Railways and rivers were classified as such edges. Then districts were analyzed. Cities were divided for smaller functional regions, mainly according to administrative divisions. Locations of office building concentrations in term of those districts were examined. As nodes in a city scale were taken transportations nodes. Train and metro stations or tram and bus stops were taken under considerations. However, transportation nodes had to be significant enough in city scale. It was usually a cross of important lines. Such transportation nodes generate people movements in local scale. District centers are located around those nodes. Various services, such as shops, restaurant, health services, administration etc., are located near nodes. Landmarks were analyzed as a last element. High and size dominant were considered as 
landmarks. As dominants mainly skyscrapers, towers, monuments and characteristic building were classified.

Office building concentration locations in the city areas were examined in aspect of five elements of mental map and then compared. That relations between office build concentration locations and each element were rated in scale from 0 to 3 points. 0 meant a lake of relations between a element and office building location. 1 point represented small impact, 2 points medium impact, 3 points significant impact. The data were collected during study visit, from open data and other available sources of information. The specific criteria's to rate office locations in aspect of each element of mental map were such as:

- paths: 0 point - location far from main roads in the city, difficult access to that roads; 1 point - location far from main roads in the city, easy access to that roads; 2 points - location near main roads in the city, road structure provides transport in two directions; 3 point - location near junction of main roads in the city, road structure provides transport in four or more directions,

- edges: 0 point - location near more that one edges, significant border; 1 point - location near one or more edges, border; 2 points - location near one or more edges, lack of negative impact; 3 point - location far from edges,

- districts: 0 points - location in low or high density residential area in suburban; 1 point - location in high density residential area far from the city center; 2 points - the location in or near downtown; 3 points - location in the city center,

- nodes: 0 point - location very far from nodes, lack of fast access to nodes; 1 point - location far from nodes, fast access to nodes; 2 points - nodes in nearest neighbourhood; 3 point - node in the area of office building concentration,

- landmarks: 0 point - lack of references to landmarks, 1 point - poor references to landmarks, 2 points -landmark in nearest neighbourhood, 3 point landmark in the area of office building concentration,

Rating for all office building concentrations were analyzed and compared. Then the medium value for each elements from all cities was done. Finally general rules and factors of office buildings locations were formulated.

\section{RESEARCH AREA}

The research area is office building concentrations in European cities. These concentrations, mainly called business district, are new urban structures in our cities. Saskia Sassen claimed that such new urban structures are caused by the global economy and new cities order [8,9]. Peter Hall indicated that three types of office centers can be defined. A-centre is exactly in a city centre. B-centre is located in downtown. C-centre occupies suburban areas [3]. As the research 
object B-centres in European cities were selected. Four characteristic office building concentrations in European cities were selected and deeply examined: Canary Wharf in London, United Kingdom, Zuidas in Amsterdam, the Netherlands, Donau City in Vienna, Austria and Służewiec Przemysłowy in Warsaw, Poland.

The Canary Wharf in located in Tower Hamlets district on the east from the City of London. It used to be dockland area until the 1970s. The Margaret Thatcher's governance decided to create here a finance center in 1975. Consequently, Canary Wharf is one of the most important business districts in the world today. London, as a one of three global cities [8, 9], generates those requirements. A need for office spaces causes that Canary Wharf is the prosperous district. It is an excellent example how global market impacts on city structure.

The second research area is Zuidas in Amsterdam in the Netherlands. This office building concertation is located on the south from the historical city centre of Amsterdam. Zuidas is cut by highway and railway. Therefore, office buildings are situated around the train and metro station Zuidas. The first investment in this area considered an infrastructure - highway A10 and railway. Then RAI Amsterdam was built in the 1980s. This conference center caused other new investments. Later on, WTC office building appeared. New office buildings have been built until know. Zuidas was built between two older districts of Amsterdam - the historical city centre on the north and residential district on the south. The biggest issue of Zuidas is highway and railway, which divide the area for two parts. Therefore, the biggest challenge for the city of Amsterdam is to join disconnected parts of Zuidas.

The third examined office building concentration is situated in Austria. It is Donau City in Vienna. Donau City is located on the northeast from the city centre. The first investment in this area was AIP centre. It is the well prosperous conference centre, which includes many office spaces. The characteristic for Donau City is fact that it is not pure office building concertation. The huge housing complex, including schools, shops, is located here. The majority of office buildings has been built after 2000. Donau City is located next to the highway number 8, metro line and metro station Kaisermühlen VIC. The residential area and huge park are the nearest neighborhood of Donau City. Such characteristic functional structure in caused by a fact that Donau City is located on an island on the Danube river. The island has mainly residential and leisure functions.

The fourth research area is Służewiec Przemysłowy, which is located in Warsaw in Poland. It is a postindustrial area in Mokotow district in Warsaw. It used to be flourishing industrial area until the beginning of the 1990s. After a shift from an industry to financed and service based economy, Sluzewiec Przemyslowe has become an attractive area for new office investments. It is the biggest office building concentration in Poland nowadays. Huge international companies are mainly located there. However, still many industrial buildings are there. 
Residential investments also appear. The biggest issue of Służewiec Przemysłowy is fact that road and public transport infrastructure is not enough for existing offices.

\section{RESULTS}

\section{Paths}

The road structure in the Great London area has two characteristic elements (Fig. 1). On one hand, a radial road structure is quite visible. Most of the roads spread out from the city centre to various directions. On the other hand, a ring road structure is also characteristic for London. Three different size rings surround the city. That system lets to transport between various districts passing the city centre. That road structure is quite efficient. The Canary Wharf area abuts a junction of two types of roads: radial and ring. Highways A1261 and A13 are part of the radial road structure. These roads make possible to transport from the London city centre to the east. What is more, Canary Wharf boards by highway A12 and A102. These roads allow moving between the south and the north of London. It is part of second ring. Canary Wharf abuts the road transportation node, which let to get to highways or change direction between south-north and east-west. Because of good access to the road transportation system, Canary Wharf has one of the best lactation in the city. Therefore, is got 3 points for paths.

Amsterdam's road structure is also quite analogical (Fig. 2). However, ring roads dominate in this city. The highway A10 is the main ring in Amsterdam, which spreads cars around the historical city centre. The shape of this road is a copy of historical road system in the city centre. A few roads create a radial system and make possible to move into the historical city centre. Zuidas is located exactly on the road A10. The highway split the office area for two parts. Two transportation nodes are on the west and the east from the Zuidas area and provide an access to the highway. Considering paths, it is one of the best location in Amsterdam. So Zuidas got also 3 points.

Highways are a base of road structure in Vienna in Austria (Fig. 3). A23 and S1 cross Vienna from the southwest to the northeast. The transportation corridor parallel to the Danube river from the northeast to the southwest is highway A22 and A4. The rest of main roads in Vienna are parallel or perpendicular to the Danube river. Therefore, main roads in Vienna have orthogonal structure. However, a radial road structure can be also indicated. Donau City is located next to a cross of two main roads in Vienna: B8 and A22. What is more, it is very significant transportation node in the city scale. Therefore, the Donau City area got 3 points for access to paths. 
The road system in Warsaw has also radial and ring structure (Fig. 4). Roads in radial system concentrate from a various direction in the city centre. That road structure bases mainly on historical origins. However, the new roads are appearing in Warsaw based on the ring structure. Służewiec Przemysłowy is also located next to the main road junction. It is a cross of radial and ring roads. Marynarska street is part of significate transportation corridor in Warsaw, which lets to move around the city centre. Służewiec Przemysłowy abuts Wloska street, which spreads cars from the city centre to the south. Because of the location next to the transportation nodes, Służewiec Przemysłowy is an attractive please for investments in Warsaw. Therefore, paths were judged also for 3 points.

Path analyzes show that roads structure has a very significant role in office building concentration locations. All examined offices are located next to the transportation nodes. What is more, it is usually junctions of one of the most important roads in the city: ring and radial road. Ring roads let to travel around city centres. The radial roads make possible to get in and out city centres. Relations between main road structures and office building concentrations are quite significant. Good access to road transportation system is significant for these investments. The reason is a need of fast and efficient transport to various destinations in cities. It could be provided by road transportation system. Therefore, road structure is so important for offices investments.

\section{Edges}

The most significant edge in London is the Tamiza river (Fig. 1). Connections between the northern and southern part of London are possible by bridges in the city centre. However, bridges are barriers for ships. Therefore, no bridges are in the east part of London on the Tamiza river. Transport between two parts of the city is possible by tunnels under the river. However, these tunnels are dedicated for cars, buses and metro. Bikes and pedestrians cannot cross the river in this part of London. Canary Wharf is located next to the Tamiza river in the East London. Contacts with neighborhood do not have significant meaning for these office buildings location. This business centre can work well instead of this edge. The other significant barrier in London is ground metro and railway lines. Metro and railway structures in London have a radial character. Ground lines are transportation corridors and barriers at the same time. That example is railway between the west and the east. Canary Wharf abuts this railway on the north. On one hand, it provides access to public transportation system by metro and railway station. On the other hand, it is a significant barrier in local and city scale. Therefore, edges got 1 point because they do not have any significant impact on office building concentration locations in London. 
The same spatial elements, ground metro and railway lines and river, are edges in Amsterdam (Fig. 2). The canal cuts the city of Amsterdam for the southern and the northern part. The railway in Amsterdam has a ring structure. It surrounds the historical city centre and then spreads in various directions. This railway line cuts the Zuidas area for two parts. Office buildings are located around the Zuidas metro and railway station. It causes that this area is divided for two unconnected parts. The highway along the railway strengthens a negative influence of this barrier. Zuidas is excellent example that edges are not an impediment for office build location. Even an edge splits an office area. Therefore, Zuidas in Amsterdam got 0 points considering edges.

The Danube river and a ground metro and railway lines are also significant barriers in Vienna (Fig. 3). The Danube river spreads for three canals and divides the city for four parts. The Donau City is situated next to the main Danube river. The river is there very width, approximately $500 \mathrm{~m}$. Therefore, connections between two parts of Vienna are quite difficult. Donau City abuts also ground metro line. This barrier separated Donau City from a residential district on the southeast. Analyzed office building concentration in Vienna abuts two edges: the river and ground metro line. A neighborhood does not seem to have any significant influence on office location. Therefore, Donau City got 1 point.

Ground railway lines and the Wisła river are the most problematic edges in the city of Warsaw (Fig. 4). The river cuts the city from the south to the north. The ground railway lines cross the city in various directions. Slużewiec Przemysłowy in Warsaw is located next to the railway from the city centre to the south. This barrier hinders to contacts between two districts. Służewiec Przemysłowy got 1 point for its location near edges.

According to analyzed case studies, edges do not have any significant influence on office building locations. It means that offices do not avoid the neighborhood of edges. What is more, case studies show that office building concentrations are located near these barriers. The most common edges are rivers and metro or railway lines. Such barriers separate office areas from the nearest neighborhood. In each case, office building concentrations abut metro or railway lines. Of course, metro or train stations provide access to public transportation system. Edges are usually border of business districts but also significant barriers. Offices are often separated from their nearest neighborhood.

\section{Nodes}

According to node definition, Canary Wharf is not located next to transportation node (Fig. 1). However, the station Canary Wharf is a very important station in the city scale. But it is not junction of metro or railway lines in various directions. Therefore, Canary Wharf got 3 points for its location and nodes. 
Transportation nodes in Amsterdam in Netherland are spread quite regularly (Fig. 2). However, more nodes are in the city centre. It mainly metro, tram or bus stops. Each node is covered up a local centre of the district. One of the most important transportation nodes in Amsterdam is located exactly in the central part of Zuidas. Therefore, Zuidas station is a heart of office area. It is significant transportation node in local, regional and even international scale. This is a reason why Zuidas got 3 points for nodes.

Nodes in Vienna were selected as railway or metro stations (Fig. 3). Connection with local service centre was also the condition to be classified as a node. The majority of transportation nodes in the city centre is near metro stations. However, suburban nodes are near railway stations. Donau City does not abut any transportation node. However, two metro stations are next to the office area. Both of them provide efficient transport to the city centre and other transportation nodes. Therefore, Donau City got 2 points for access to nodes.

As nodes in Warsaw in Poland, train and metro stations were classified (Fig. 4). Junctions of at least a few tram or bus lines were also considered as nodes. The majority of transportation nodes is located along the metro line. Each metro station is a transportation node and local centre at the same time. The reason could be the fact that only one metro line is in Warsaw. No nodes are in the neighborhood of Służewiec Przemysłowy. The nearest transportation node is the metro station Wilanowska. However, it is approximately $1 \mathrm{~km}$ away from Służewiec Przemysłowy. Considering access to nodes, Służewiec Przemysłowy got 1 point.

Nodes are not so important elements for office building concentration locations. Transportation nodes do not have to be located on office building areas. However, efficient and fast access to those nodes has to be provided. Instead of Amsterdam, all analyzed office building concentrations are located next to metro or railway stations, but not transportation nodes.

\section{Districts}

The London area was divided for smaller regions according to the administrative division (Fig. 1). Canary Wharf is located in a downtown area, between the City of London on the west and residential district on the east. However, Canary Wharf is situated nearer a board with a residential district on the east. It is quite a characteristic edge location between downtown and residential districts. Therefore, Canary Wharf got 3 points.

The functional structure of Amsterdam has quite typical characteristic (Fig. 2). It is a radial structure. The historical city centre is in the central part of the city area. Then a chain of downtown and industry is. The third ring is a residential district. Zuidas is located exactly on the edge of downtown and residential area. A board is highway and railway lines. However, the office area fits more to the 
downtown district. But access to a residential district is also provided. Therefore, Zuidas got 3 points for its characteristic location.

The Vienna functional structure is also quite regular (Fig. 3). A division for the city centre, downtown and residential districts is quite clear. However, that division is unsettled because of the Danube river. More industry and green area is near the river. Doanu City in Vienna has also edge location, but not so characteristic as in other cities. The Danube river is here significant barrier. Therefore, Donau City got 2 points.

Districts in Warsaw were also marked according to administrative areas (Fig. 4). The district structure in Warsaw is quite typical. The city centre structure is in the central part of the city area. Downtown district is next ring around the city centre. Then typical residential districts are. Służewiec Przemysłowy is located on the edge between downtown and residential districts. It is downtown area, but next to the board with residential district. It is typical edge location. On one hand, it is quite central location. On the other hand, it is not so far from residential areas. Hence, Slużewiec Przemysłowy got 3 points for districts.

All analyzed office building concentrations have similar locations in term of district elements. They are on edge of two districts: downtown and residential. Downtown districts are not as significant as a city centres. However, they are still attractive districts, where many important activities are located. On the other hand, residential districts also abut offices. These locations have origins of city history. These areas used to be places of industry development in XIX century, outside historical city centres. However, a shift to financial and service base economy caused postindustrial development. District elements for Bcentres were judged very high for 3 points. It means that districts have significant influence on office building locations, especially for B-centres.

\section{Landmarks}

Characteristic monuments were taken under consideration as landmarks in London

(Fig. 1). All of them are big enough to dominate in the city scale. The majority is located along the Tamiza river. It causes that all monuments are even more visible. Main examples of landmarks in London are: One Canada Square, Tower Bridge, Big Ben, City Hall, 3D Mary Axe etc. One Canada Square is the landmark in Canary Wharf. A city urban composition and high of this skyscraper cause that it is landmark even in the city scale. It is easily visible along the Tamiza river from the City of London. That the reason why Canary Wharf got 3 points for landmarks.

The majority of landmarks in Amsterdam in the Netherlands is located in the historical city centre (Fig. 2). Monumental or characteristic buildings mainly are landmarks. Churches or train station often are taken under consideration as 
landmarks. However, skyscrapers in Zuidas are also a landmark in the city scale, which are only high dominants in the city of Amsterdam. Therefore, Zuidas got maximum 3 points.

The most important landmarks in Vienna in Austria are also located in the city centre Leopoldstadt (Fig. 3). The majority is historical and public buildings. Many landmarks are located along the Viennese ring. Such characteristic building as Schonbrunn palace, windmill in Prater or chimney are also considering as landmarks. Skyscrapers in Donau City also belong to this group. They are the most characteristic high dominants in Vienna. The location next to the Denude river make them even more visible. That is the reason why Donau City got also 3 points for landmarks.

The most characteristic landmarks in Warsaw are in the city centre (Fig. 4). It is Palace of Culture and Science, hotel Merlot, hotel Continental and other skyscrapers along the Jerozolimska street and Jana Pawla street. Two characteristic monuments are situated along the Wisla river: the castle in historic part of the city and national stadium. Both of them are characteristic landmarks in Warsaw panorama. The building of Mokotowska commercial center and skyscrapers in Służewiec Przemysłowy are also characteristic landmarks in local and city scale. Especially concentration of skyscrapers next to the junction of Marynarska and Woloska street. However, they are not main landmarks in the city scale. Hence, Służewiec Przemysłowy got 2 points.

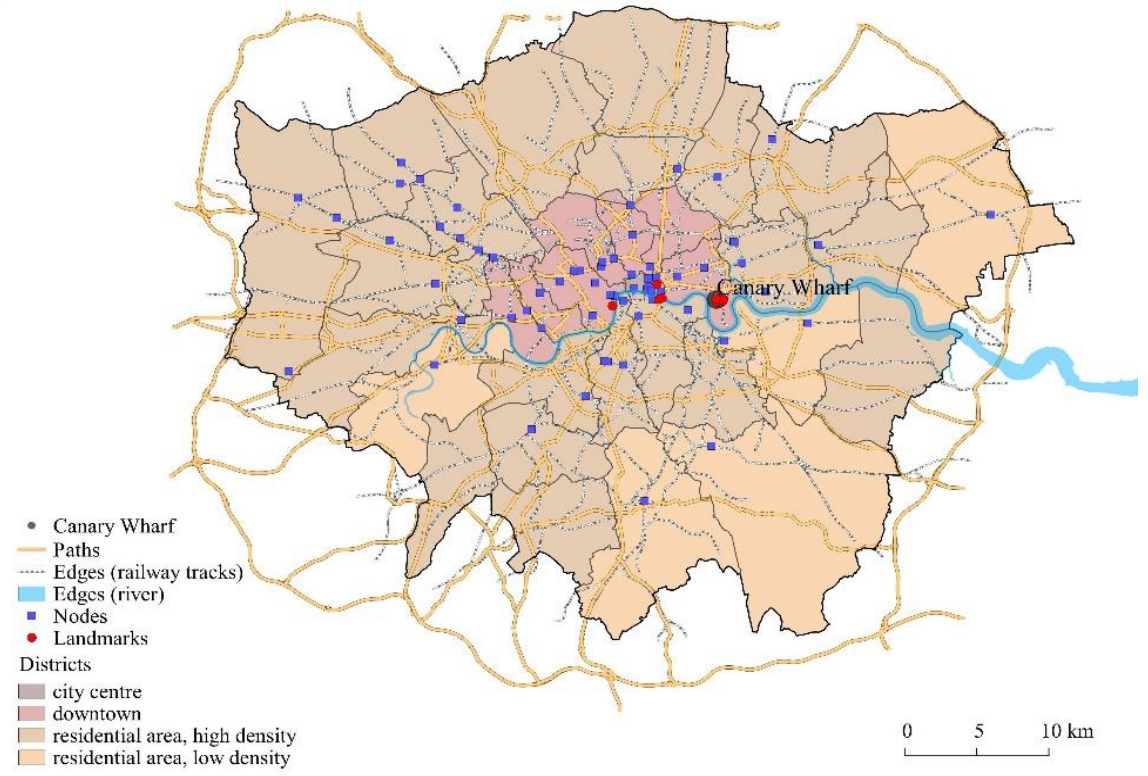

Fig. 1. The mental map of London and Canary Wharf location 


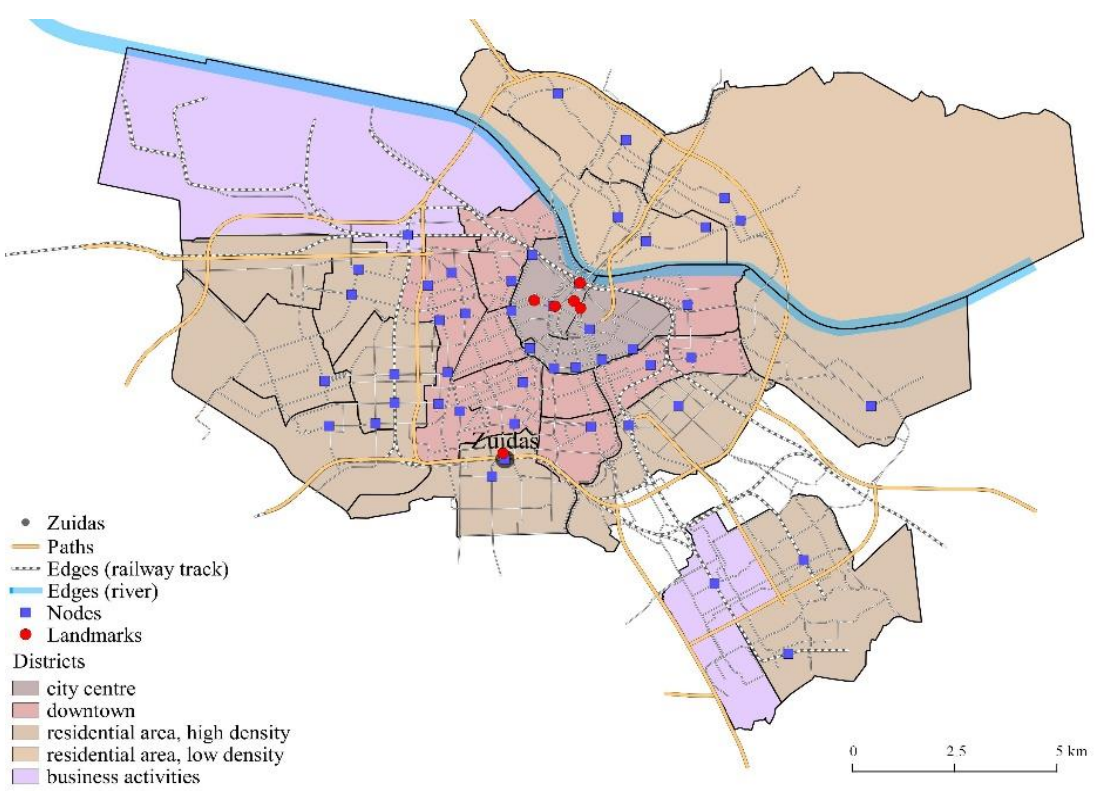

Fig. 2. The mental map of Amsterdam and Zuidas location

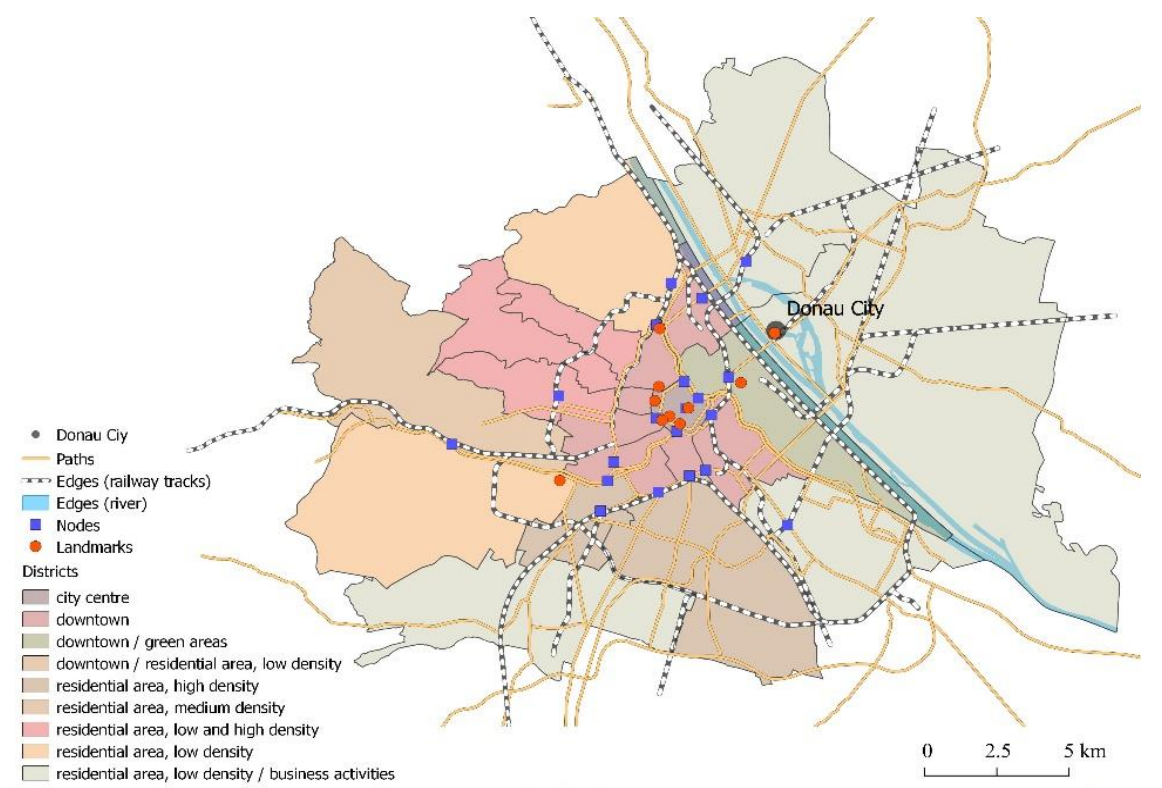

Fig. 3. The mental map of Vienna and Donau City location 

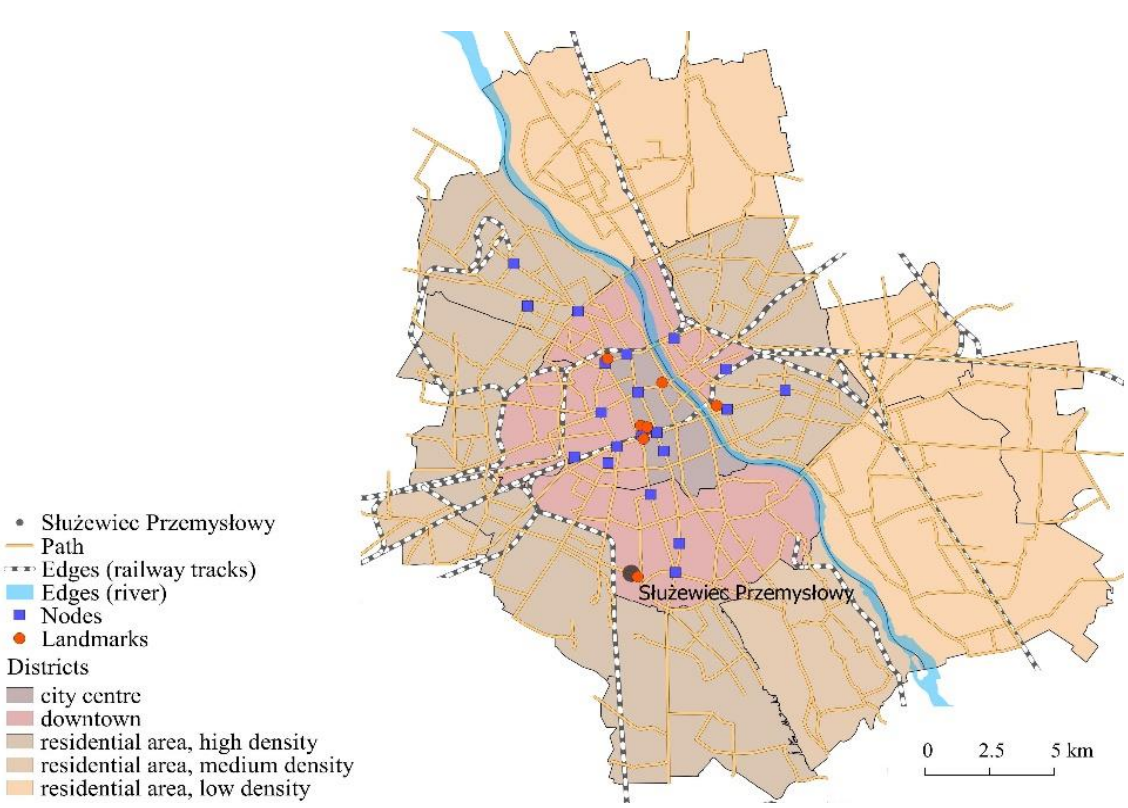

Fig. 4. The mental map of Warsaw and Służewiec Przemysłowy location

The most significant landmarks in selected cities were analyzed. Mainly buildings were taken under considerations. Those characteristic buildings were situated mainly in city centers. However, every examined office building concentrations included on their areas any landmarks. Skyscrapers were that landmarks. Characteristic axes between city centres and landmarks in office areas were in London, Vienna and Warsaw. Landmarks are quite typical for office building concentrations. However, these landmarks are rather consequences of office investments than land conditions. But they can be taken under consideration during next office locations.

\section{DISCUSSION}

Research results show that relations between city urban compositions and office building locations exist (Fig. 5). All analyzed case studies, as B-centres, have similar locations in term of mental map elements. What is more, the same urban composition elements have similar meaning for each office building concentrations. Of course, differences are observed. Local conditions and various city structures are a reason of these discrepancies. But similarities are still quite strong. 


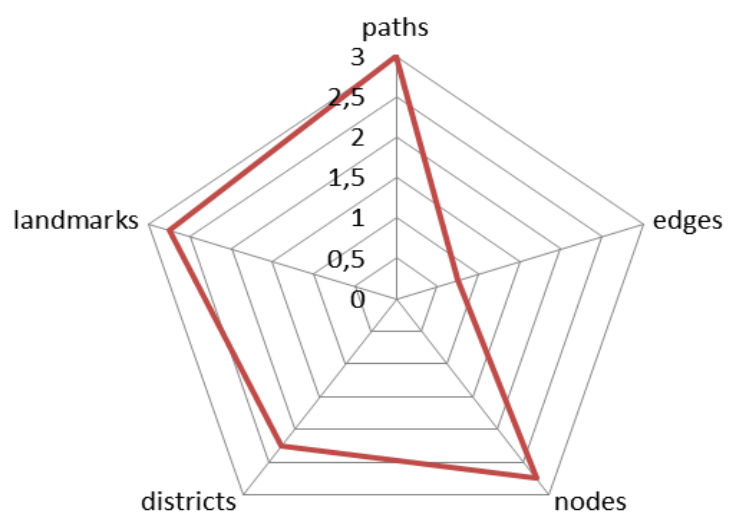

Fig. 5. Average values of urban composition elements

Paths have a significant role in office building concentration locations (avg. $3,0)$. Main road structures in cities have a big influence. Office building concentrations are located near the most important roads in cities. Such locations provide access to road transportation system. It is provided by transportation nodes near main road junctions. Road transport to various destinations is provided. Therefore, paths in terms of main roads are very important for offices locations. Edges have also meaning for office locations. However, their influence is opposite than other elements (avg. 0,75). Office building concentrations are indifferent to edge influences. Connections with surrounding areas are not so important for offices. Therefore, these barriers do not disturb on office locations. On the other hand, it causes that business districts are like a citadels $[6,7]$. They aim to have access to transportation nodes and efficient transport to other city destinations. Nodes for offices are not so important as it seems to be (avg. 2,25). Of course, access to the efficient public transportation system is always provided. However, railway or metro stations usually are not the most important transportation nodes in cities. However, good access to those nodes should be provided, especially to the city centres. Districts have also significant meaning for office building locations (avg. 2,75). On one hand, B-centers are located in downtown. On the other hand, each district was situated on an edge of two districts: downtown residential area. It is caused probably by industrial origins of those areas. Landmarks are also very important elements for office buildings (avg. 2,75). Each analyzed business district was a landmark or included landmark. Skyscrapers are mainly landmarks. But it is rather a consequence that reason. However, it could be motivations for next office investments. 


\section{CONCLUSION}

Research presents what kinds of indicators have influence on office building locations. What is more, the power of each indicator was examined. Research results proved that style in office building concentration location exist. Various elements of city structure compositions have influences on these infestations. That knowledge should support decision-making process. Is should let better plan and manage these urban structures to make them more sustainable and attractive.

The project is co-financed by the European Union as part of the European Social Fund

\section{REFERENCES}

1. Florida R., The Rise of the Creative Class, New York, Basic Books 2002.

2. Glaeser E., Triumh of the cities, New York, The Pengiun Press 2011.

3. Hall P., Good Cities Better Lives, How Europe Discovered the Lost Art of Urbanism, London and New York, Routledge 2014.

4. Lynch K., Obraz miasta, Kraków, Wydawnictwo Archivolta 2011.

5. Majoor S. J. H., The Disconnected Innovation of New Urbanity in Zuidas Amsterdam, Ørestad Copenhagen and Forum Barcelona, „European Planning Studies", 9, 17 (2009),1379-1403.

6. Marcus P., Space in the Globalizing City, in: The Global Cities Reader, London, Routledge 2006, 362-369.

7. Marcuse P., Kempen R., Globalizing Cities: A New Spatial Order, Oxford, Blackwell Publishing Ltd 2000.

8. Sassen S., The Global City, New York, London, Tokyo, Princeton University 2001.

9. Sassen S., Cities in a World Economy. Thousand Oaks, Pine Forge Press 2006.

10. Majoor S. J. H., The Disconnected Innovation of New Urbanity in Zuidas Amsterdam, Ørestad Copenhagen and Forum Barcelona. European Planning Studies, 9, 17 (2009).

11. Zipser T., Sławski J., Modele procesów urbanizacji: teoria $i$ jej wykorzystanie $w$ praktyce planowania, Warszawa, Państwowe Wydawnictwo Ekonomiczne1988. 


\section{CZYNNIK STYLU JAKO DETERMINANTA LOKALIZACJI KONCENTRACJI BUDYNKÓW BIUROWYCH W EUROPEJSKICH MIASTACH}

\section{Streszczenie}

Koncentracje budynków biurowych są stosunkowo nową i charakterystyczną tkanką miejską w Europie. Jako skupisko miejsc pracy w mieście oraz lokalizacja wielu międzynarodowych firm są istotną strukturą przestrzenną, pożądaną przez lokalne władze. Ze względu na znaczenie ich projektowanie powinno być poprzedzone odpowiednimi analizami. Jednym $\mathrm{z}$ istotnych zagadnień jest wybór odpowiedniej lokalizacji dla budynków biurowych na obszarze miasta.

Gdzie powinny być lokalizowane skupiska budynków biurowych, jakie czynniki wpływają na ich położenie na obszarze miasta to główne pytania prowadzonych badań. W tym celu zbadano czynniki lokalizacji wybranych koncentracji budynków biurowych na terenach śródmiejskich w europejskich miastach. Wnikliwie przeanalizowano styl jako jeden $z$ elementów paradygmatu decyzji przestrzennych. Przez styl należy rozumieć zasady i reguły istniejącego układu przestrzennego. Przeanalizowano najważniejsze elementy kompozycji przestrzennej wybranych miast oraz położenie badanych koncentracji budynków biurowych. Analizy porównawcze pozwolą określić czy istnieją jakiekolwiek zależności w lokalizacji koncentracji budynków biurowych względem układu kompozycyjnego całego miasta. Umożliwi to zdefiniowanie grupy czynników, które wpływają na ich lokalizację w mieście. Taka wiedza powinna być podstawą przy sporządzaniu opracowań planistycznych, określających zasady kształtowania i lokalizacji takich inwestycji.

Słowa kluczowe: budynki biurowe, dzielnice biznesowe, kompozycja przestrzenna

Editor received the manuscript: 07.08.2015 